\title{
Coffee (Coffea arabica L,var. Castillo) seedling growth in Nariño, Colombia
}

\author{
Crecimiento en almácigo de café (Coffea arabica L,var. Castillo) \\ en Nariño, Colombia
}

José Álvaro Castillo; Danita Andrade²

\begin{abstract}
ARTICLE DATA
1 Professor, M.Sc., Universidad de Nariño, Pasto, Colombia, jacastillomarin@yahoo.com

2 Researcher, M.Sc., Grupo de Investigación en Producción de Frutales Andinos (GPFA), Universidad de Nariño, Pasto, Colombia, danitaan@ gmail.com
\end{abstract}

Cite: Castillo, J.A.; Andrade, D. (2021). Coffee (Coffea arabica L,var. Castillo) seedling growth in Nariño, Colombia. Revista de Ciencias Agrícolas. 38(1): 62-74. doi: https://doi.org/10.22267/rcia.213801.145

Received: October 262020 Accepted: March 102021.

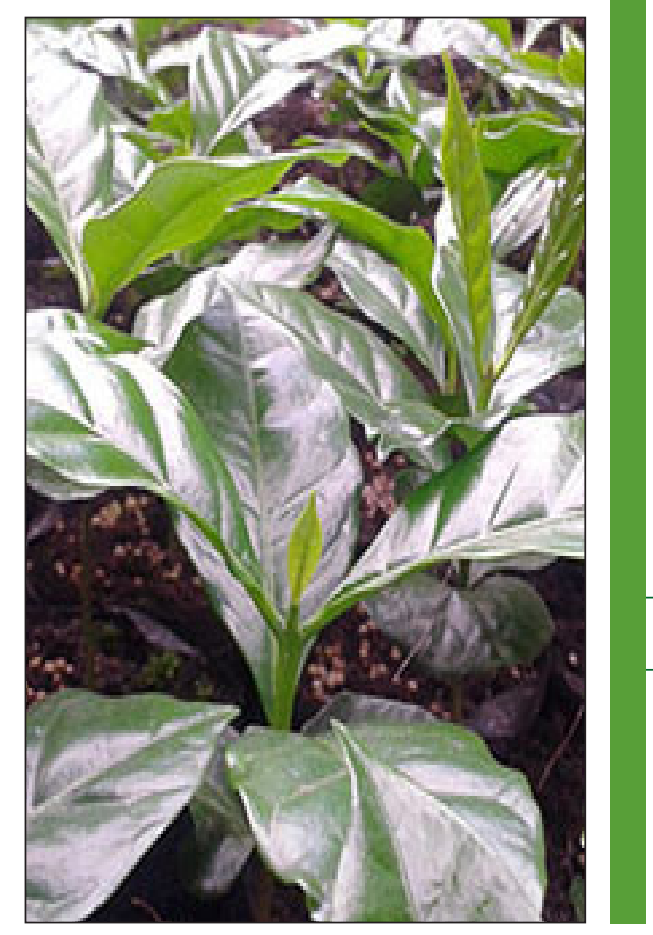

UNIVERSIDAD DE NARIÑO e-ISSN 2256-2273

\begin{abstract}
Coffee is one of the most socioeconomically important crops worldwide. Currently, environmental variations due to climate change are affecting coffee development and growth. Therefore, it is important to evaluate areas that offer a different environment during seedling stage since it is fundamental for successful cultivation. Four municipalities located at different altitudes in the Department of Nariño were selected: La Florida (1879 m a.s.l.), Sandoná (1924 m a.s.l.), Consacá (2001 m a.s.l.), and La Unión (1417 m a.s.l.). The experiment was conducted as a randomized complete block design. Growth variables were measured for five months, including total height-TH, number of leaves-NL, total leaf area-LA, fresh weight-FW, and dry weight-W. The following indices were calculated from the variables recorded: relative growth rate-RGR, leaf area index-LAI, net assimilation rate-NAR, crop growth rate-CGR, leaf area duration-LAD, and leaf area ratio-LAR. The data related to $\mathrm{TH}, \mathrm{NL}, \mathrm{W}$, and LA recorded during the last evaluation (120 days after being transplanted) showed differences between locations; the maximum values in TH, $\mathrm{W}$ and LA were recorded in La Union, while higher averages in NL were obtained in Sandoná. The index values for CGR, LAI, LAR, RGR, and LAD were higher in La Unión, while NAR was higher in La Florida. The results lead to conclude that there are differences in coffee seedling growth depending on the climatic conditions. Accordingly, the highest growth was observed in areas at lower altitudes; therefore, these are recommended for seedling establishment given the higher growth rate, especially that of leaves.
\end{abstract}

Keywords: coffee; environment; development; growth rates; seedlings.

\section{RESUMEN}

El café es uno de los cultivos de mayor importancia socioeconómica alrededor del mundo. Actualmente las variaciones ambientales debidas al cambio climático afectan su desarrollo y crecimiento. Siendo importante evaluar zonas con diferentes ofertas ambientales durante la etapa de almacigo, considerando que es la base para el éxito de un cultivo de café. 
Se seleccionaron cuatro municipios en el departamento de Nariño a diferentes altitudes: La Florida (1879msnm), Sandoná (1924msnm), Consacá (2001 msnm) y La Unión (1417msnm). El experimento se realizó en un diseño de bloques completes al azar. Durante cinco meses, se registraron variables de crecimiento: altura total-AT, número de hojas-NH, área foliar total-AF, masa fresca-WF y masa seca-W. A partir de estas se calcularon índices derivados: tasa relativa de crecimiento-TRC, índice de área foliar-IAF, tasa de asimilación neta-TAN, tasa de crecimiento del cultivo-TCC, duración de área foliar-DAF y relación de área foliar-RAF. Los datos de AT, NH, W y AF registrados en la última evaluación (120 días después del trasplante) muestran diferencias entre localidades. Los valores máximos en AT, W y AF se presentaron en La Unión, mientras que los promedios superiores en NH se obtuvieron en Sandoná. Las variables TCC, IAF, RAF, TRC y DAF presentaron mayores índices en La Unión, mientras que TAN en La Florida. Concluyendo que hay diferencias en el crecimiento de plántulas de café según las condiciones climáticas donde se estén desarrollando, por cuanto se recomiendan localidades con menor altitud para el establecimiento de almácigos dado el mayor crecimiento obtenido, siendo las hojas la sección de mayor influencia.

Palabras clave: café; ambiente; desarrollo; índices de crecimiento; plántulas.

\section{INTRODUCTION}

Coffee (Coffea arabica L) cultivation is a highly profitable economic activity in several Latin American countries. Furthermore, it determines the subsistence of several sectors of the population given the diverse activities and income that are generated across the value chain (i.e., from cultivation to consumption) (Bucardo et al., 2016; García et al., 2017; Robiglio et al., 2017; Gil, 2019; Molina et al., 2020).

In Colombia, coffee production occupied nearly 742.3 thousand hectares in 2018, with a production of 855 thousand tons. Specifically, $4.51 \%$ of the crop area 33.465 ha) and $4.17 \%$ of the production (35.679 tons) were provided by the Department of Nariño. This coffee-growing area is located near the equator at altitudes ranging from 1200 to $2300 \mathrm{~m}$ a.s.l., covering a wide range of production systems (Agronet, 2020; Ordóñez et al., 2018).

Given the broad socioeconomic importance and extensivecultivation of coffee, Government and non-governmental organizations (NGOs) must focus on addressing the impact of climate conditions on coffee growth, production, and pest and diseases (Bucardo et al., 2016; García et al., 2017; Robiglio et al., 2017; Gil, 2019; Molina et al., 2020).

Currently, and as predicted for the XXI century, climate change is affecting different crops, including coffee (García et al., 2017; Alfonse et al., 2018). This is due to weather variability, which directly affects perennial crop growth and development (Farfán, 2016).

Several environmental factors (e.g., climatic, edaphic, and biotic) may affect coffee growth, development, and physiological processes. For instance, high altitudes favor the concentration of elements in rubbish dump. Furthermore, climatic factors, such as light intensity or radiation, precipitation, temperature, and $\mathrm{CO}_{2}$, determine which areas are ecologically suitable for coffee crop development. However, in regions with marked dry periods, the response of coffee is more influenced by precipitation or soil humidity, while in regions without soil water deficit, coffee response is related to radiation and the phenological stage of the 
crop (Melo and Piñeros, 2015; Rodríguez et al., 2015; Robiglio et al., 2017; García et al., 2017; Borjass et al., 2018; Milla et al., 2019; Vega et al., 2020).

As an adaptive strategy of the coffee production industry to climatic variability, the Federación Nacional de Cafeteros of Colombia (National Federation of Coffee Growers of Colombia) proposes planting improved varieties, renovating coffee plantations, and conducting research focused on climate change (Farfán, 2016). Furthermore, detailed studies at the farm and landscape levels are necessary to determine how the climate affects the different phenological stages of the crop (Molina et al., 2020). This highlights the importance of conducting research on seedlings of coffee Castillo variety to propose solutions in the face of climate change.
In this sense, this research aimed to evaluate the growth of $C$. arabica Castillo variety at different altitudes in the municipalities of La Florida, Sandoná, Consacá, and La Unión in the Department of Nariño. This study contributes knowledge to optimize resources and aid in decision-making when it comes to coffee seedling management.

\section{MATERIALS AND METHODS}

Location. This study was conducted during the first semester of 2014 in four municipalities of the Department of Nariño: La Florida vereda Santana at 1846 m a.s.l., Sandoná vereda San Isidro at 1880 m a.s.l., Consaca vereda San Antonio at $2001 \mathrm{~m}$ a.s.l., and La Unión vereda La Playa at 1417 m a.s.l., under the climatic conditions described in Table 1.

Table 1. Climatic Parameters of the study areas for seedling establishment in four municipalities of the Department of Nariño- Colombia: La Unión, Sandoná, La Florida, and Consacá.

\begin{tabular}{lcccc}
\hline \multicolumn{1}{c}{ Bioclimatic Variable } & La Unión & Sandoná & La Florida & Consacá \\
\hline Mean temperature $\left({ }^{\circ} \mathrm{C}\right)$ & 20.8 & 17.7 & 18 & 16 \\
Mean daily temperature (maxtemp - mintemp; $\left.{ }^{\circ} \mathrm{C}\right)$ & 10.5 & 10.2 & 10.2 & 10 \\
Maximum temperature of the hottest month $\left(\mathrm{Tmax} ;{ }^{\circ} \mathrm{C}\right)$ & 27.5 & 23.6 & 24.1 & 21.6 \\
Minimum temperature of the coldest month $\left(\mathrm{Tmin} ;{ }^{\circ} \mathrm{C}\right)$ & 15.2 & 12.2 & 12.4 & 10.5 \\
Thermal amplitude $\left(\mathrm{Tmax}-\mathrm{Tmin} ;{ }^{\circ} \mathrm{C}\right)$ & 12.3 & 11.4 & 11.7 & 11.1 \\
Mean temperature of the most humid trimester $\left({ }^{\circ} \mathrm{C}\right)$ & 20.3 & 17.4 & 17.6 & 15.9 \\
Mean temperature of the driest trimester $\left({ }^{\circ} \mathrm{C}\right)$ & 21.2 & 17.8 & 18.2 & 16 \\
Solar brightness $\left(\right.$ wat $\left./ \mathrm{m}^{2}\right)$ & 529.91 & 351.71 & 444.07 & 322.75 \\
Photosynthetically Active Radiation $\left(\mu \mathrm{M} / \mathrm{m}^{2} \mathrm{~s}\right)(\mathrm{PAR})$ & 1049.16 & 720.82 & 902.96 & 659.47 \\
\hline
\end{tabular}


The evaluation of the variables was done at the laboratory of Plant Physiology of the Faculty of Agricultural Sciences at Universidad de Nariño, Pasto.

Plant material. In the four municipalities, Coffee Castillo "Tambo" variety was planted in flat seed beds with guadua (Guadua angustifolia Kunth), in an area of $1.5 \mathrm{~m}^{2}$ per kilogram of planted seed. The substrate was washed river sand $(0.30 \mathrm{~m}$ thick $)$ that was disinfected with hot water $\left(90^{\circ} \mathrm{C}\right)$. After an average of 90 days, "chapola" plants (i.e., coffee plant stage in which cotyledon leaves are noticeable) were obtained and transplanted in $1 \mathrm{Kg}$ bags filled with a mix of sand and organic matter (3:1). The seedlings were covered with $30 \%$ polyshade and agronomic management was done according to the recommendations from Cenicafé and Federación Nacional de Cafeteros de Colombia (2013).

Experimental design. A randomized complete block design was used, in which the blocking factor corresponded to the altitude and climate of the sites where the study seedlings were located.

Variables evaluated. Evaluations were carried out every 15 days on 20 randomly selected seedlings for a total of nine evaluations. The total height (TH) was measured from the base of the stem to the apex with a ruler in centimeters and the number of leaves (NL) was based on the direct count.

Plant material sampling. In each evaluation, two seedlings were randomly extracted to evaluate the following variables in the laboratory: total leaf area (LA) in square centimeters by applying the leaf length-dependent model, where $L A=\left(\frac{4.541+(2.38 * T H)}{1+(0.154 * T H)+\left(0.0075 * T H^{2}\right)}\right) * L_{L} ;$ fresh weight (FW) was determined through direct weighing, and dry weight (W) was estimated by oven-drying each organ (e.g., stem, leaves, and roots) at $60^{\circ} \mathrm{C}$ for $72 \mathrm{~h}$ to quantify the total $\mathrm{W}$ and $\mathrm{W}$ of each fraction, in grams $(g)$.

The variables measured were used to calculate indices such as the relative growth rate (RGR), leaf area index (LAI), net assimilation rate (NAR), crop growth rate (CGR), leaf area duration (LAD), and leaf area ratio (LAR), according to the equations shown in Table 2 (Gardner et al., 1985).

Data analysis. The data obtained for each variable were consolidated in an Excel spreadsheet and analyzed based on the Functional Analysis of Growth methodology, which uses measurements based on frequent time intervals with a small number of plants, using a regression model (Gardner et al., 1985). 
Table 2. Components of growth parameters determined in coffee Castillo "Tambo" variety seedlings.

\begin{tabular}{|c|c|c|c|}
\hline Growth indices & Abbreviation & Equation for mean value & Units \\
\hline Relative Growth Rate & RGR & $\frac{\ln W_{2}-\ln W_{1}}{T_{2}-T_{1}}$ & $\begin{array}{c}\text { Weight } * \text { Weight }{ }^{-1} * \text { Time }^{-1} \\
g * g^{-1} * d^{-1}\end{array}$ \\
\hline Net Assimilation Rate & NAR & $\frac{W_{2}-W_{1}}{T_{2}-T_{1}} * \frac{\ln L A_{2}-\ln L A_{1}}{L A_{2}-L A}$ & $\begin{array}{c}\text { Weight } * \text { Area }^{-1} * \text { Time }^{-1} \\
g * \mathrm{~cm}^{-2} * d^{-1}\end{array}$ \\
\hline Leaf Area Index & LAI & $\frac{L A_{2}-L A_{1}}{A s}$ & Adimensional \\
\hline Leaf Area Ratio & LAR & $\frac{\left(\frac{L A_{1}}{W_{1}}\right)+\left(\frac{L A_{2}}{W_{2}}\right)}{2}$ & $\begin{array}{l}\text { Area } * \text { Weight } \\
\quad \mathrm{cm}^{2} * d^{-1}\end{array}$ \\
\hline Crop Growth Rate & CGR & $\frac{1}{A s} * \frac{W_{2}-W_{1}}{T_{2}-T_{1}}$ & $\begin{array}{c}\text { Weight } * \text { Area }^{-1} * \text { Time }^{-1} \\
\qquad g * \mathrm{~cm}^{-2} * d^{-1}\end{array}$ \\
\hline Leaf Area Duration & LAD & $\frac{\left(L A I_{1}+L A I_{2}\right)\left(T_{2}-T_{1}\right)}{2}$ & $\begin{array}{c}\text { Time } \\
d\end{array}$ \\
\hline
\end{tabular}

Symbols used: W=Total Dry Weight; T=Time; LA=Leaf Area; As=Soil area; ln=Natural Logarithm.

\section{RESULTS AND DISCUSSION}

In the four municipalities, TH increases over time (Figure 1). However, the seedlings in La Unión showed higher values since the first evaluation, reaching a height of $14.5 \mathrm{~cm}$. The TH of seedlings in Consacá, Sandoná, and La Florida were lower, as indicated by means of $8.28,7.83$, and $6.25 \mathrm{~cm}$, respectively. Borjas et al. (2018) report a height range similar to the one found here, specifically, between 7.56 and $13.89 \mathrm{~cm}$. However, these heights are lower than those reported by Álvarez (2019), who obtained an overall mean of $16.56 \mathrm{~cm}$.

The data recorded for $\mathrm{TH}$ in the municipalities of La Unión and La Florida displayed a second-degree polynomial behavior, while TH in Consacá and Sandoná adjusted to a linear model (Figure 1). Furthermore, the predictive models for La Unión and La Florida vary according to the values obtained for the predictive variable, while in Consacá and Sandoná, these values are direct and constant.

Regarding temperature (Table 1), La Unión showed the highest values, thus promoting growth. Higher temperatures are associated with a higher photosynthetic assimilation rate, which is directly related to growth. Moreover, the effect of temperature is observed in the duration of the phenological stages. However, this study demonstrates that higher altitudes lead to reduced growth of the aerial part of the plant due to lower temperatures (Cenicafé and Federación Nacional de Cafeteros de Colombia, 2013; Gil, 2019). 


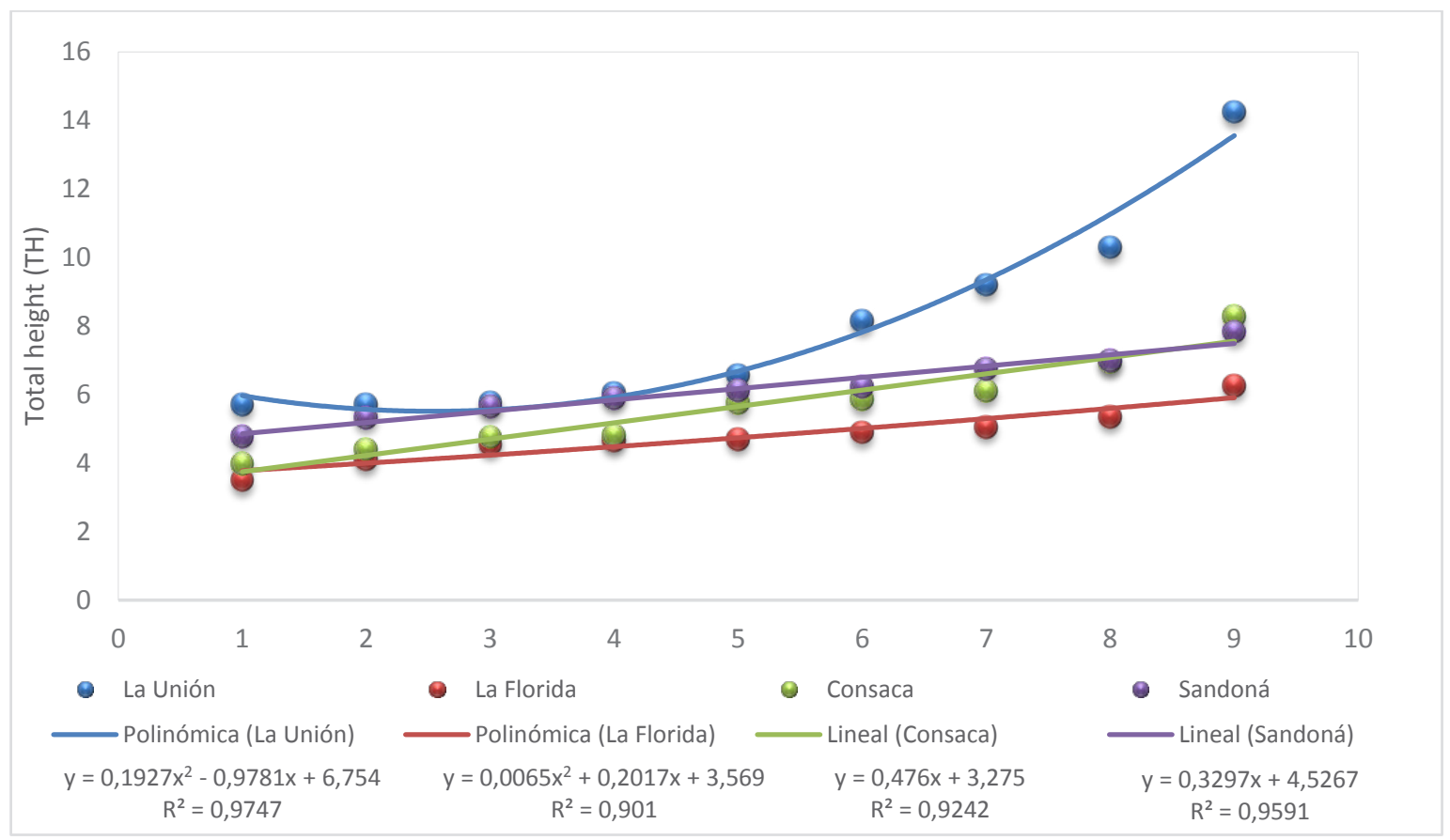

Figure 1. Total height of coffee seedlings evaluated in four coffee-growing municipalities in southern Colombia.

The rate of leaf emergence showed constant growth with mean values ranging from one to two leaves every 15 days (Figure 2). Leaf development is related to solar brightness and photosynthetically active radiation since there is evidence that leaf formation is constant; furthermore, different degrees of shade generate more or a fewer number of leaves (Milla et al., 2019).

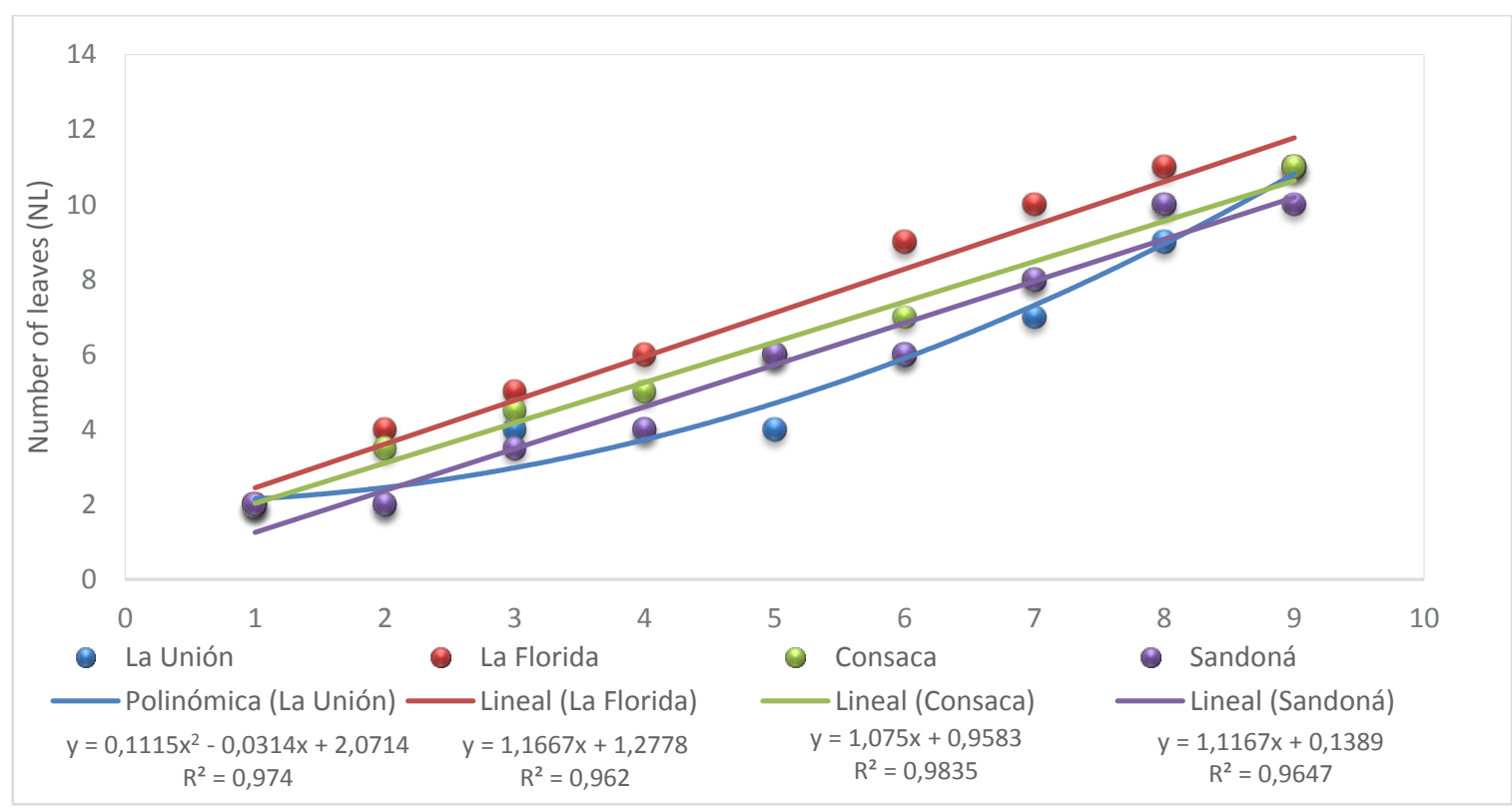

Figure 2. Number of leaves of coffee seedlings evaluated in four coffee-growing municipalities in southern Colombia. 
The seedlings in the municipality of La Florida showed a higher and constant rate of leaf emergence across the nine evaluations, in contrast to the other municipalities where the same number of leaves was observed across successive evaluations. However, in the last evaluation, the plants in La Unión and Consacá showed 11 leaves each (Figure 2).

In this regard, Borjas et al. (2018) obtained a higher number of leaves (14 leaves) at the 60-day evaluation. The importance of this variable lies in the direct relationship between the number of leaves and leaf area, as well as between these two variables and growth. The leaf surface is responsible for carbon assimilation, nutrient and water use, evapotranspiration, development rate, and photosynthetic efficiency (Cenicafé and Federación Nacional de Cafeteros de Colombia, 2013; Montoya et al., 2017; Gil, 2019).
In the four localities, the increase in NL was modeled by linear equations, except in La Unión, where it adjusted to a second-degree polynomial. The coefficients of determination were significant $\left(R^{2}>0.96\right)$, indicating a good fit. According to Letort et al. (2020), there is an almost linear branching growth, reaching 14 knots with a pair of true leaves and stabilizing at a constant value of 1 . This growth trend allows quantifying the increase in the number of leaves adjusted to a power function. In contrast, Borjas et al. (2018) obtained first and second-degree equations to model the increase in NL. However, in this research, only La Unión obtained results similar to reports in the literature, possibly due to a higher temperature, solar brightness, and radiation (Table 1) in this locality. Conversely, the other three municipalities showed lower mean values for these climatic variables.

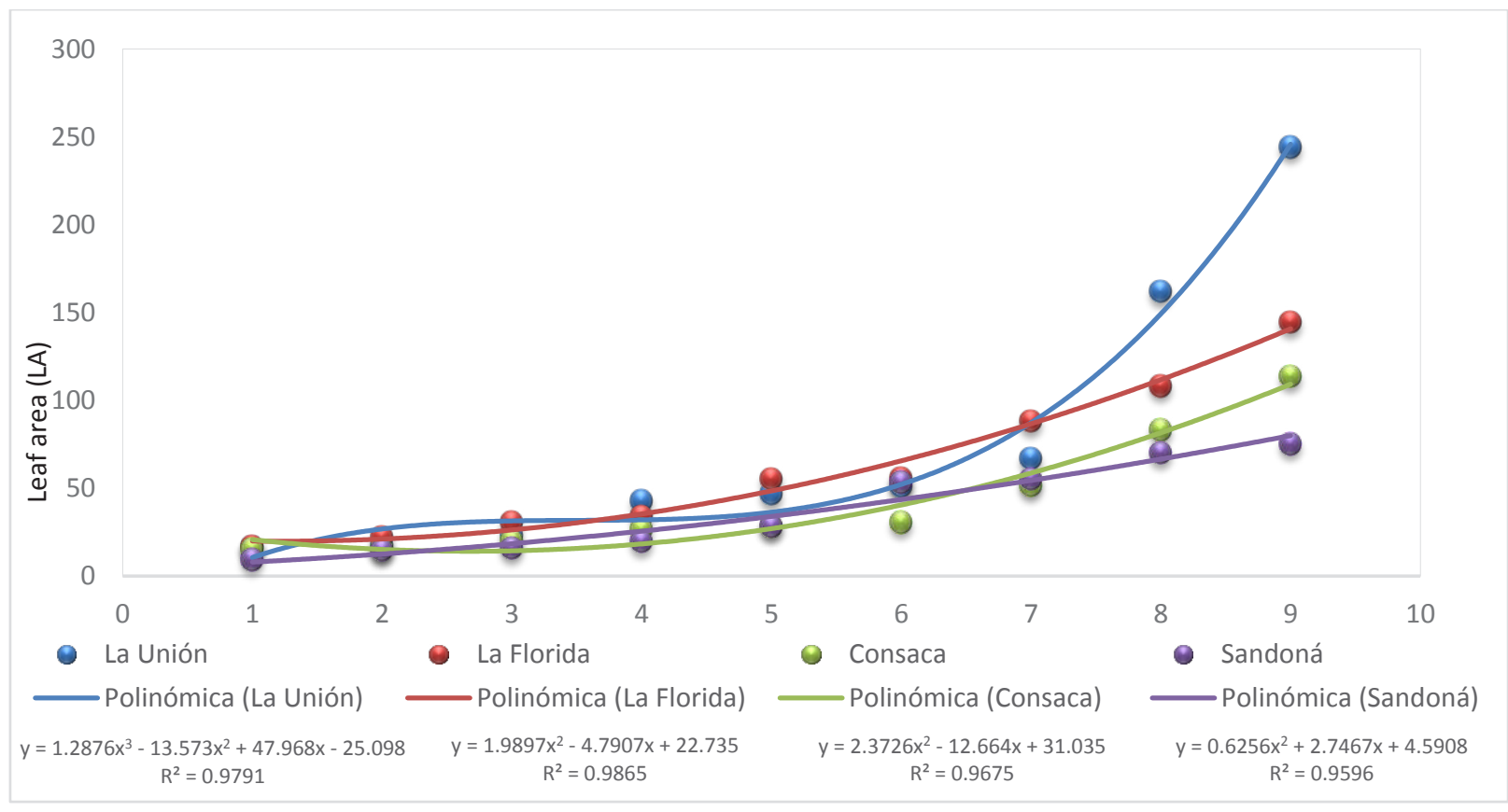

Figure 3. Leaf area of coffee seedlings evaluated in four coffee-growing municipalities in southern Colombia. 
The highest mean value for LA was obtained in La Unión $\left(244.05 \mathrm{~cm}^{2}\right)$, followed by $\mathrm{La}$ Florida $\left(125.05 \mathrm{~cm}^{2}\right)$, Consacá $\left(112.84 \mathrm{~cm}^{2}\right)$, and Sandoná $\left(75.21 \mathrm{~cm}^{2}\right)$. However, the four municipalities showed an increase in LA over time that adjusted to a polynomial model (Figure 3). The model showed a good fit, indicated by an $\mathrm{R}^{2}$ greater than 0.95 for the four localities, which demonstrated the validity of the growth indices derived from the LA variable.

Additionally, studies based on comparisons of leaf area across robusta and arabica coffee plants report significant increases between four- and seven-month periods in response to temperature (Vega et al., 2020).

Regarding W, the seedlings from the municipality of La Unión reached a high mean dry weight (2.26g), followed by La Florida (1.61g), Sandoná (1.23g), and Consacá (1.18g). Seedling development was explained by a third-degree polynomial for La Unión and a second-degree polynomial for the other municipalities. $\mathrm{R}^{2}$ values ranging from 94 to 98\% were obtained for the models (Figure 4). These results demonstrate the effect of temperature on the dry matter accumulation rate and growth of coffee seedlings (Cenicafé and Federación Nacional de Cafeteros de Colombia, 2013; Montoya et al., 2017; Gil, 2019).

On the other hand, seedling growth, expressed as mean fresh weight, in the four localities, indicated that the leaves accounted for the highest percentage $(65.88 \%)$ of the total weight, followed by the stem (32.06\%) and roots $(2.06 \%)$. However, in the last evaluations, root growth was greater than leaf and stem growth (Figure 5A).

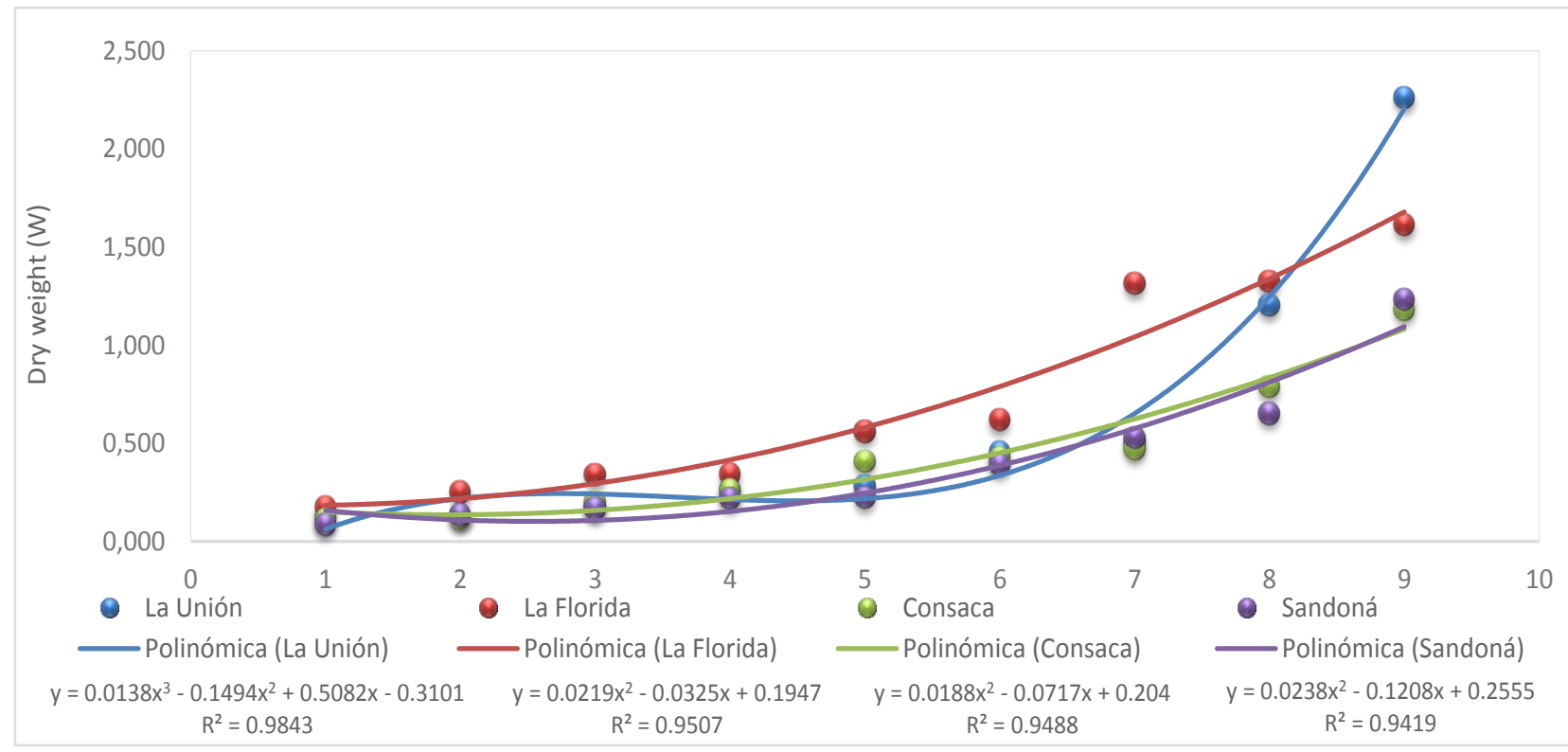

Figure 4. Dry weight of coffee seedlings evaluated in four coffee-growing municipalities in southern Colombia. 

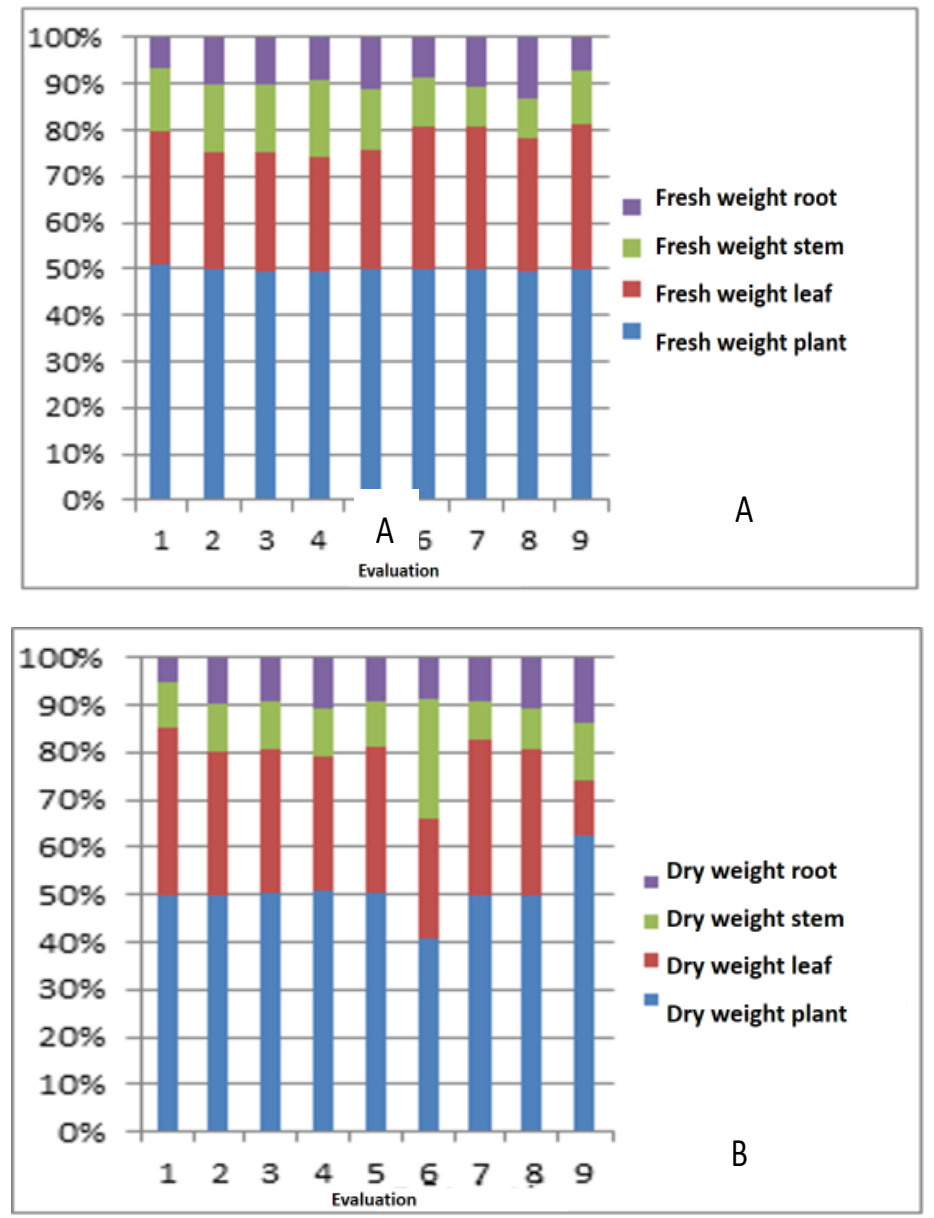

Figure 5. Distribution of fresh weight (A) and dry weight (B) of coffee (Coffea arabica L) Castillo variety seedlings over time in four localities.

Similar to the results found here, Borjas et al. (2018) reported greater biomass in the aerial part of the plant compared to the roots. However, there is a balance between the leaf area or total photosynthetic surface for the production of assimilates and the root surface area for absorption of water and minerals. Nonetheless, the root/aerial part ratio (R/ $\mathrm{AP})$ gradually decreases with age since there is higher accumulation of carbohydrates and root development. Additionally, $\mathrm{CO}_{2}$ and temperature have significant effects on aerial biomass accumulation between four and seven months of development of arabica and robusta coffee. However, at 12 months, arabica showed an increase in several plant parameters in response to $\mathrm{CO}_{2}$, while robusta was unaffected by $\mathrm{CO}_{2}$ (Vega et al., 2020).

The dry weight of each plant part and its relationship with the total weight showed that $72.55 \%$ of the dry weight corresponded to the leaves (finding also observed for fresh weight), followed by the roots and stem (Figure 5B).

Given these findings, the stem has a high proportion of water and low dry matter, while the leaves are the main contributors to the total plant weight. These results are in 
line with those of Encalada et al., (2016), who report that the greatest contribution to the total dry weight was made by the leaves and roots. Moreover, as described for NL variable, the results demonstrate the effect of the temperature, as well as solar brightness and photosynthetically active radiation, on fresh and dry biomass. Similarly, other studies demonstrate that $20 \%$ light exposure promotes greater dry mass and specific leaf area (Cenicafé and Federación Nacional de Cafeteros de Colombia, 2013; Encalada et al., 2016; Montoya et al., 2017; Gil, 2019).

On average, in the seedling developmental stage of coffee Castillo variety, $83 \%$ of the plant is water and $17 \%$ is dry matter. Letort et al. (2020) describe a progressive increase in the relationship between offer and demand of biomass in seedlings, corresponding to the establishment of the plant architecture, represented by a gradual increase in organ size and the appearance of the first branches.

On the other hand, RGR varied across evaluations in the four localities, displaying the lowest dry matter accumulation between evaluations. The highest and lowest RGR were observed at the seventh and eighth evaluations in La Unión and La Florida, respectively (Figure 6A). Gil (2019) mentions that temperatures above $24^{\circ} \mathrm{C}$ accelerate plant growth compared with low temperatures that delay development.

The NAR also varied across all evaluations in the four municipalities; for instance, in La Florida, it reached a maximum value $\left(0.00067 \mathrm{~g} \mathrm{~cm}^{-2} \mathrm{~d}^{-1}\right)$ at 105 days (Figure 6B). This behavior is explained by Rodríguez et al. (2015), who described that the leaf system of coffee trees exposed to high solar radiation showed lower sizes, greater histological thickness of the palisade parenchyma, and higher stomatal frequency.

Alower number of leaves and leafarea exposed to radiation, concomitantly with higher NAR values, indicates that $\mathrm{CO}_{2}$ assimilation is more efficient. The NAR is a measure of the net gain of assimilates per unit leaf area unit and unit time (Gardner et al., 1985).

The maximum LAI was obtained at the eighth and ninth evaluations in the municipality of La Unión, while the lowest value (0.39) was obtained at the same evaluation periods in Sandoná (Figure 6C). The LAI varies according to the size, number, and vertical and horizontal distributions of the foliage. Therefore, leaf growth parameters in coffee seedlings are determined by leaf supporter axis order and position along the vertical profile, as well as duration of leaf expansion. Accordingly, these parameters suggest the effects of age and micro-environmental light modulation on growth (Rakocevic and Takeshi, 2018).

For LAR, the highest values were obtained at 75 days (fifth evaluation) in La Unión, at 60 days in La Florida, and 30 days in Sandoná and Consacá (157.5, 96.3, 104.03, and $130.8 \mathrm{~cm}^{2 *} \mathrm{~d}^{-1}$, respectively) (Figure 6D). These findings suggest a maximum photosynthetic capacity and low respiratory cost since almost all leaves are exposed to the LAR during the seedling stage. Furthermore, plants use a greater fraction of photoassimilates for the growth and development of photosynthetically active areas, thus, generating energy expenditure that leads to lower weight (Cenicafé and Federación Nacional de Cafeteros de Colombia, 2013). 

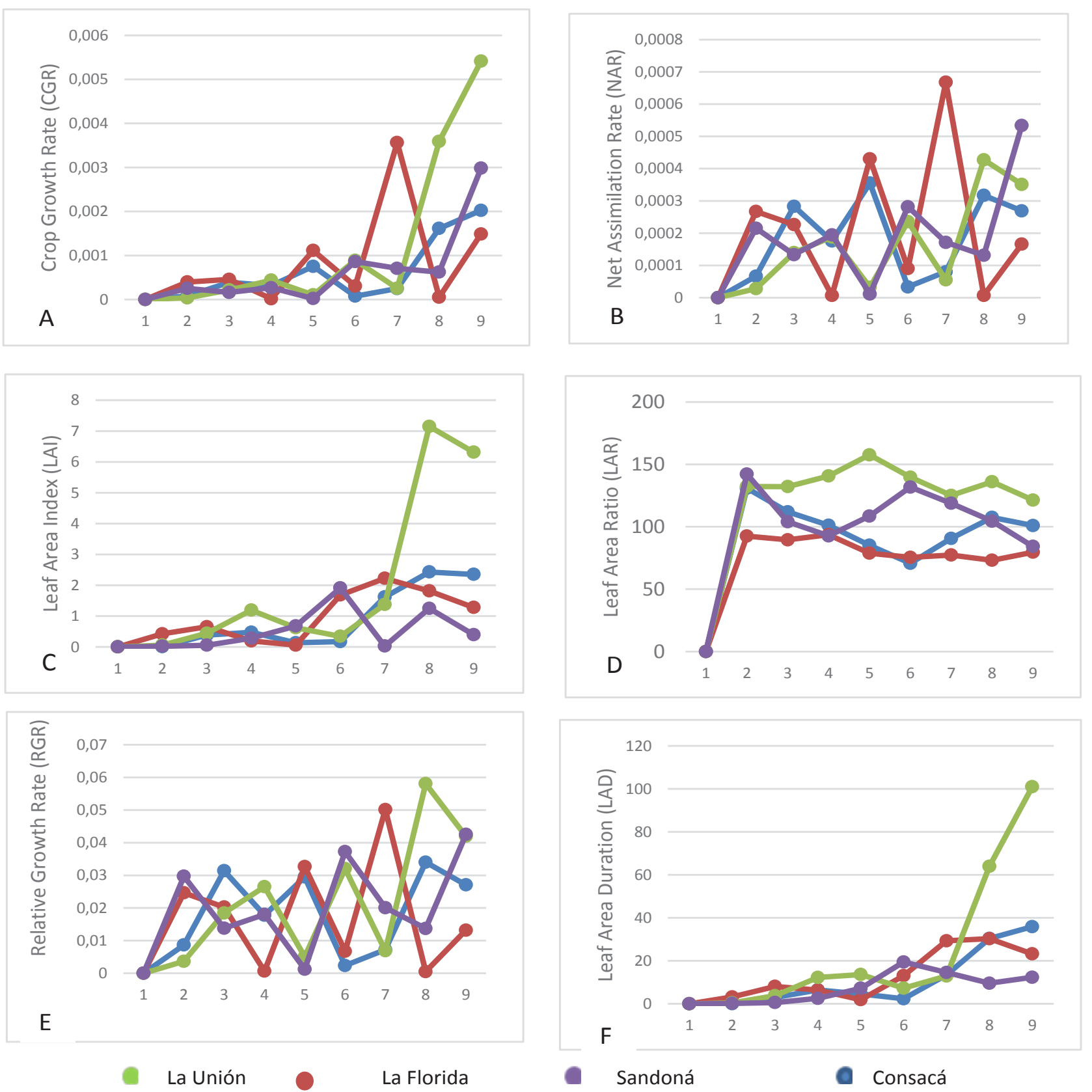

Figure 6. Growth indices of coffee seedlings in the municipalities of Consaca, Sandoná, La Unión, and La Florida: A) Relative Growth Rate, B) Net Assimilation Rate, C) Leaf Area Index, D) Leaf Area Ratio, E) Crop Growth Rate, and F) Leaf Area Duration.

Crop growth rate (CGR) under the environmental conditions of the four localities was low until the seventh evaluation (105 days). From this moment, the plants in La Unión, Sandoná, and Consacá showed a progressive increase, reaching maximum values at 135 days, as indicated by mean CGRs of $0.0054 \mathrm{~g}^{*} \mathrm{~cm}^{-2 *} \mathrm{~d}^{-1}$ in La Unión, $0.0029 \mathrm{~g}^{*} \mathrm{~cm}^{-}$ ${ }^{2 *} \mathrm{~d}^{-1}$ in Sandoná, and $0.0020 \mathrm{~g}^{*} \mathrm{~cm}^{-2 *} \mathrm{~d}^{-1}$ in Consacá. In La Florida, the greatest dry biomass accumulation per unit of soil area $\left(0.0035 \mathrm{~g}^{*} \mathrm{~cm}^{-2 *} \mathrm{~d}^{-1}\right)$ was obtained at 105 days. 
The results show that the maximum mean CGR values in the four localities were reached at the last evaluations. These findings agree with those of Letort et al. (2020), who mention that biomass production per unit of time displays a sigmoid trend, considering the saturation generated by the auto-shading effect of the leaves as the plant grows.

The maximum LAD was observed in plants in the municipality of La Unión at the last evaluation (135 days), followed by the plants in Consacá, La Florida, and Sandoná $(100.9,35.8,23.2$, and 1.3 days, respectively). This index is associated with LAI over time and represents leaf production capacity during crop growth. LAD is also related to the dramatic effect of the first leaf drop on biomass production, which depends on several factors such as the environment and phenological stage (Cenicafe and Federación Nacional de Cafeteros de Colombia, 2013; Letort et al., 2020).

\section{CONCLUSIONS}

The locality in La Unión, situated at lower altitude with higher temperature, showed the highest means for the direct variables and derived indices.

In all localities, the stems displayed the lowest fresh and dry weights in response to the progressive growth of the aerial parts of the plant and the highest accumulation of dry matter in the leaves. This is explained by the fact that leaf area has the greatest effect on coffee plant weight during seedling stage.

The temperature conditions are widely associated with the altitude of the localities in this study and directly affect the variables analyzed. Therefore, at higher altitude, plant growth, dry weight of the aerial part, number of leaves per plant, and dry weight are lower.

Conflict of interest: The authors declare that there is no conflict of interest.

\section{BIBLIOGRAPHIC REFERENCES}

Alfonse, A.; Trejo, J.; Martínez, M. (2018). Opción climática para la producción de café en México. Ensayos Revista de Economía. 37(2): 135-154. doi: http://dx.doi.org/10.29105/ ensayos37.2-1

Álvarez, W. (2019). Evaluación de los efectos nutricionales del lombricompuesto y las Micorrizas Arvasculares, en el desarrollo de un almácigo de café Coffea arábica L. Recovered from https://repository.unad. edu.co/bitstream/handle/10596/28437/ waalvarezq.pdf? sequence $=1 \&$ isAllowed $=y$

Borjass, R.; Andía, E.; Alarcón, G.; Estelita, S.; Julca, A. (2018). Crecimiento y calidad de plántulas de café (Coffea arabica) injertadas sobre Coffea canephora frente a nematodos en vivero. Journal of the Selva Andina Biosphere. 6(2): 28-41. doi: http://dx.doi. org/10.36610/j.jsab.2018.060200028

Bucardo, E.; Van Zonneveld, M.; Betanco, B.; Francisco, B. (2016). Recomendaciones para una caficultura sostenible adaptada al clima en Huehuetenango, Guatemala y las Segovias, Nicaragua. Recovered from https://ccafs.cgiar. org/es/publications/ recomendaciones-parauna-caficultura-sostenible-adaptada-al-climaen-huehuetenango\#.X5ReA1hKipo

Cenicafé - Centro Nacional de Investigaciones de Café; Federación Nacional de Cafeteros de Colombia. (2013). Manual del cafetero colombiano. Investigación y tecnología para la sostenibilidad de la caficultura. Tomo I y II. Chinchina, Caldas, Colombia: Cenicafe. 285 p.

Encalada, M.; Soto, F.; Morales, D.; Álvarez, I. (2016). Influencia de la luz en algunas características fisiológicas del cafeto (Coffea arabica L. cv. 
Caturra) en condiciones de vivero. Cultivos Tropicales. 37(4): 89-97. doi: http://dx.doi. org/10.13140/RG.2.2.10544.76801

Farfán, F. (2016). Sombríos transitorios para el establecimiento del café. Manizales, Caldas: Cenicafé. 27p.

García, M.; Gustavo, M.; Castañeda, Ernesto; Lozano, S.; Pérez, M. (2017). Caracterización del agroecosistema de café bajo sombra en la cuenca del río Copalita. Revista Mexicana de Agronegocios. 40(1): 635-648.

Gardner, F.; Pearce, R.; Mitchell, R. (1985). Physiology of crop plants. Ames: Lowa State University Press. 21(95): 327. doi: 10.1016/ 0378-4290(86)90065-1

Gil, J. (2019). Indicadores bióticos del cambio climático: casos granadilla y café. Revista Yachay. 8(1), 522-529. doi: https://doi. org/10.36881/yachay.v8i1.130

Letort, V.; Sabatier, S.; Okoma, M.; Jaeger, M.; Reffye, P. (2020). Internal trophic pressure, a regulator of plant development? Insights from a stochastic functional-structural plant growth model applied to Coffea trees. Annals of Botany. 126(4): 687-699. doi: https://doi. org/10.1093/aob/mcaa023

Melo, R.; Piñeros, R. (2015). Evaluación de la fertilización edáfica en café (Coffea arabica L.) mediante el análisis sensorial y características físicas bajo diferentes alturas en FusagasugaCundinamarca. Recovered from

http://repositorio.ucundinamarca.edu.co/ handle/20.500.12558/70

Milla, M.; Oliva, S.; Leiva, S.; Silva, R.; Gamarra, O.; Barrena, M.; Maicelo, J. (2019). Características morfológicas de variedades de café cultivadas en condiciones de sombra.Acta Agronómica. 68 (4): 271-277. doi: https://doi.org/10.15446/ acag.v68n4.70496.

Agronet - Red de Información y Comunicación del Sector Agropecuario. (2020). Reporte: Área, Producción y Rendimiento Nacional por Cultivo. Recovered from https://www. agronet.gov.co/estadistica/Paginas/home. aspx?cod=1
Molina, P.; Gómez, M.; Ortiz, G.; Cerdan, C.; Pérez, J. (2020). Fenómenos meteorológicos y su efecto sobre la producción de café en la Zona Central de Veracruz. UVserva. 9(1): 47-58. doi: https:// doi.org/10.25009/uvserva.v0i9.2638

Montoya, R.; Hernandez, A.; Unigarro, M.; Florez, R. (2017). Estimación del área foliar en café variedad Castillo a libre exposición y su relación con la producción. Revista Cenicafe. 68(1): 55-61.

Ordóñez, H.; Navia, J.; Ballesteros, W. (2018). Tipificación de sistemas de producción de café en La Unión Nariño, Colombia. Temas Agrarios. 24(1): $53-65$.

Rakocevic, M.; Takeshi, F. (2018). Variations in leaf growth parameters within the tree structure of adult Coffea arabica in relation to seasonal growth, water availability and air carbon dioxide concentration. Annals of Botany. 122: 117-131. doi: https://doi.org/10.1093/aob/ mcy042

Robiglio, V.; Baca, M.; Donovan, J.; Bunn, C.; Reyes, M.; Gonzáles, D.; Sánchez, C. (2017). Impacto del cambio climático sobre la cadena de valor del café en el Perú. Cali, Colombia: ICRAF Oficina Regional para América Latina, Lima, Perú \& CIAT Centro Internacional de Agricultura Tropical. 53p.

Rodríguez, L.; Hernández, F.; Gómez, H.; Fonseca, M.; Gómez, J.; Pinto, R. (2015). Anatomía foliar relacionada con la ruta fotosintética en árboles de café (Coffea arabica L., var. Caturra Rojo) expuestos a diferentes niveles de radiación solar en la Sierra Maestra, Granma, Cuba. Acta Agronómica. 65 (3): 248-254. doi: http:// dx.doi.org/10.15446/acag.v65n3.46731

Vega, F.; Ziska, L.; Simpkins, A.; Infante, F.; Davis, A.; Rivera, J.; Barnaby, J.; Wolf, J. (2020). Early growth phase and caffeine content response to recent and projected increases in atmospheric carbon dioxide in coffee (Coffea arabica and C. canephora). Scientific Reports. 10: 5875. doi: https://doi.org/10.1038/s41598-02062818-x 